\title{
Antitrust Damage Claims: A View from EFTA Court*
}

\author{
Agata Jurkowska-Gomułka**
}

ABSTRACT: Articles 101 and 102 TFEU have become a pattern for competition rules provided in Articles 53 and 54 of the EEA Agreement, which entered into force on 1 January 1994. Both EU competition law and EEA competition law can be enforced before national courts. Lodging damage claims in the EU was facilitated by Directive 2014/104/EU. The so-called Antitrust Damages Directive was highly inspired by the jurisprudence of the Court of Justice of the European Union. Although Directive 2014/104/EU has not been incorporated into the EEA law, damage claims resulting from violations of EEA competition rules are judged by national courts in the EEA Member States, which is why some aspects of private enforcement of competition law have become a point of interest for the EFTA Court, being - together with the Court of Justice of the European Union - the EEA court. Firstly, the article aims at checking if the EFTA Court jurisprudence on antitrust damage claims follows the guidelines formulated in the case law of the Court of Justice. Since the positive answer to this question is highly probable, secondly, the article aims at identifying the extent of the impact of EU jurisprudence in private enforcement cases on judgments of the EFTA Court. The article concludes that the EFTA Court's activities regarding antitrust damage claims follow the route indicated by the Court of Justice of the European Union. Four identified judgments regarding - directly or indirectly - antitrust damage claims (Nye Kystlink, Fjarskipti, Schenker I and Schenker V), delivered by the EFTA Court, seem to strengthen its position as an institution that is able to guarantee a coherence between EEA and EU competition law. EFTA Court's judgments in private

\footnotetext{
* DOI: https://doi.org/10.7559/mclawreview.2019.1829.

** Agata Jurkowka-Gomułka is a Professor of Law at the University of Information Technology and Management, Faculty of Administration and Social Sciences, Chair of Administrative Science, 35-225 Rzeszow, Poland, ajurkowska@wsiz.rzeszow.pl.

She is also Of-counsel at law boutique Modzelewska\&Paśnik, Warsaw, Poland.
} 
enforcement cases are also a point of interest and reference for EU Advocates General and can become an inspiration for both $\mathrm{EU}$ and national case law.

KEYWORDS: damage claim, Antitrust Damage Directive, EEA, EFTA Court, private enforcement

\section{Introduction}

Private enforcement of competition law has been a hot topic for researchers, legislators and practitioners in the EU - a lot of emotions were generated by a process of adoption and implementation of the so-called Antitrust Damages Directive ${ }^{1}$. Currently, this emotional wave touches the Court of Justice of the European Union (hereinafter, CJEU), which is facing cases with the Antitrust Damages Directive in their background - in March 2019, two important judgments were delivered (cases Cogeco ${ }^{2}$ and Skansk $\mathrm{a}^{3}$ ). Jurisdiction on private enforcement of competition law seems about to erupt in the nearest months and years. The current (pre-Directive) case law on private enforcement of Articles 101 and 102 TFEU will be developed and in some cases - verified due to the Directive's rules, and hopefully - deepened in terms of the number and nature of legal problems to be solved by the CJEU.

A prohibition of anticompetitive agreements and of abuse of a dominant position in the European Economic Area (hereinafter, EEA) are contained, correspondingly, in Articles 53 and 54 of the Agreement on the European Economic Area ${ }^{4}$ (hereinafter, the EEA Agreement or EEA). Both articles repeat the contents of Articles 101 and 102 TFEU.

The Antitrust Damages Directive has not been incorporated into the EEA Agreement ${ }^{5}$, so there is no obligation in the EEA to apply the provisions laid down in that directive, including the rules on limitation periods.

\footnotetext{
${ }^{1}$ Directive 2014/104/EU of the European Parliament and of the Council of 26 November 2014 on certain rules governing actions for damages under national law for infringements of the competition law provisions of the Member States and of the European Union, OJ 2014 L 349, 1-19.

2 Judgment of the Court of Justice of 28 March 2019, Cogeco Communications Inc v. Sport TV Portugal SA and Others, C-637/17, EU:C:2019:263.

${ }^{3}$ Judgment of the Court of Justice of 14 March 2019, Vantaan kaupunki v. Skanska Industrial Solutions Oy and Others, C-724/17, EU:C:2019:204.

${ }^{4}$ Agreement on the European Economic Area, OJ 1994, L 1, 3-36.

${ }^{5}$ This is a situation for the end of June 2019. See a negative comment on that at https://www.nordiccompetitionblog.com/?p=744.
} 
Furthermore, insofar as the Damages Directive lays down rules that are not a codification of EEA-relevant case law, there is no obligation in the EEA to ensure the same result as in the EU under that directive. Consequently, EEA law does not set out the procedural rules concerning the right to claim damages for breaches of Articles 53 and 54 EEA.

The goal of this article is to check, firstly, whether EFTA Court's activities follow this EU tendency of developing the private enforcement of competition law. The question is extremely relevant in situations where the Antitrust Damages Directive has not been incorporated into EEA law. Secondly, the article aims at identifying the influence of CJEU jurisprudence on the approach of the EFTA Court regarding problems arising from the enforcement of competition rules before national courts. It must, however, be underlined that the key points of interest of this article are judgments related to antitrust damage claims, and not necessarily to other aspects of private enforcement of competition law, such as the nullity of anticompetitive practices.

\section{Materials and methods}

A key method applied in this article is the case study in a comparative perspective: EFTA Court and CJEU. A statistical approach to case law is also applied in a marginal scope. Moreover, the article also refers to some doctrinal resources (books and articles).

The article focuses on the analysis of the EFTA Court's case law available at the EFTA Court's website. Research (ended in April 2019) allowed for an identification of four judgments concerning antitrust damage claims. Two of them are fully dedicated to enforcing competition law before a civil court, whereas in two other cases antitrust damage claims are only a context of the court dispute, but important enough to be dealt with by the EFTA court. The case law of the CJEU is regarded as a point of reference for the analysis of EFTA judgments - answering questions lying behind this article requires references to the most significant judgments of the EU law in the following cases: Courage ${ }^{6}$, Manfredi ${ }^{7}$,

\footnotetext{
${ }^{6}$ Judgment of 20 September 2001, Courage Ltd v. Bernard Crehan and Bernard Crehan v. Courage Ltd and Others, C-453/99, EU:C:2001:465.

${ }^{7}$ Judgment of 13 July 2006, Vincenzo Manfredi v. Lloyd Adriatico Assicurazioni SpA (C-295/04), Antonio Cannito v. Fondiaria Sai SpA (C-296/04) and Nicolò Tricarico (C-297/04) and Pasqualina Murgolo (C-298/04) v. Assitalia SpA, EU:C:2006:461.
} 
Pfleiderer ${ }^{8}$, Otis ${ }^{9}$, Donau Chemie ${ }^{10}$, Kone ${ }^{11}$, and CDC Hydrogen Peroxide Cartel Damage Claims ${ }^{12}$.

\section{Judgements on private enforcement before the EFTA Court}

\subsection{E-10/17 Nye Kystlink AS v. Color Group AS and Color Line AS}

\subsubsection{Facts of the case}

The most recent judgment was delivered on 17 September 2018 in case E-10/17 - Nye Kystlink AS v. Color Group AS and Color Line $A S^{13}$. It was a preliminary ruling responding to a reference from Borgarting Court of Appeal. A preliminary question from the Norwegian court focused on the interpretation of the principles of equivalence and effectiveness in the context of national rules on the limitation period for claims for damages in cases fined on the basis of Articles 53 and 54 of the EEA Agreement. Nye Kystlink and Color Line are both Norwegian ferry companies operating between Scandinavian countries. Color Line operates ferries between Sandefjord, in Norway, and Strömstad, in Sweden, since 1986. In 1991, the company entered into a harbour agreement with the Municipality of Strömstad. On the basis of this agreement, Color Line got an exclusive access to an area at Torskholmen reserved for ferry operations. The agreement was valid for a period of 15 years (from 1 January 1991 to 30 December 2005) and included an option for Color Line to extend it by 10 years. In 2000, Kystlink started a ferry service between Langesund, in Norway, and Hirtshals, in Denmark, which was intended to compete with Color Line's service between Larvik and Hirtshals. Three years later, in 2003, Kystlink decided to offer a new passenger ferry service between Langesund, in Norway, and Strömstad, in Sweden. This route was intended to compete with Color Line's service between Sandefjord and Strömstad.

\footnotetext{
${ }^{8}$ Judgment of 14 June 2011, Pfleiderer AG v. Bundeskartellamt, C-360/09, EU:C:2011:389.

${ }_{9}^{9}$ Judgment of 6 November 2012, Europese Gemeenschap v. Otis NV and Others, C199/11, EU:C:2012:684.

${ }^{10}$ Judgment of 6 June 2013, Bundeswettbewerbsbehörde v. Donau Chemie AG and Others, C536/11, EU:C:2013:366.

${ }^{11}$ Judgment of 5 June 2014, Kone AG and Others v. ÖBB-Infrastruktur AG, C557/12, EU:C:2014:1317.

${ }^{12}$ Judgment of 21 May 2015, Cartel Damage Claims (CDC) Hydrogen Peroxide SA v. Evonik Degussa GmbH and Others, C-352/13, EU:C:2015:335.

${ }^{13}$ English version of the judgment at https://eftacourt.int/wp-content/uploads/2019/01/10_17 Judgment_EN.pdf.
} 
Kystlink applied for a permission from the Municipality of Strömstad to use the port for these new ferry activities. As a result, the Municipality of Strömstad decided to grant Kystlink access to the port for a trial period of two years from the start-up date (21 December 2005). It happened before the 15-year harbour contract with Color Line had expired because the Municipality found the exclusivity clause incompatible with competition law. An extension of the harbour agreement with Color Line was also denied by the local authorities. Kystlink lodged a complaint with the Norwegian Competition Authority. Because of cross-border issues in the case, the complaint was transferred to the ESA. Although the complaint raised three potential infringements of competition law, the ESA, in the statement of objections issued on 16 December 2009, focused only on the exclusivity clause and did not address other issues. In the decision dated from 2011, the ESA claimed that Color Line infringed Articles 53 and 54 by concluding a harbour agreement with a long-term exclusivity clause. The ESA imposed a fine of EUR 18811 000. The decision was not appealed against and became final on 14 February 2012. On 14 December 2012, Kystlink filed a complaint against Color Line with a conciliation board, including a claim for damages, and it interrupted the limitation period. On 6 February 2014, Kystlink brought an action against Color Line to Oslo District Court, claiming damages for financial losses limited upwards to NOK 1300000000 for infringement of Articles 53 and 54 EEA. Kystlink invoked all the circumstances that had been mentioned in its complaint to the Norwegian Competition Authority and even highlighted some other points that occurred after the complaint to the Competition Authority was lodged. The damage claim was dismissed by the court of first instance on the basis of the fact that the limitation period had expired. The judgment was appealed against and the court of second instance decided to submit a preliminary ruling to the EFTA Court.

\subsubsection{Legal issues}

Norwegian law provides two regulations on limitation periods that could possibly be applied in the case. Section 9(1) of the Limitation Act states that "A claim for damages or redress lapses three years after the date on which the injured party obtained or should have procured necessary knowledge about the damage and the responsible party". As it is underlined in the EFTA Court's judgment (paragraph 6): "It follows from Norwegian case law that the limitation period for claiming damages under this provision 
starts from the time that the injured party had or should have procured knowledge about the factual circumstances to enable it to bring an action "with the prospect of a positive outcome". Another expression of this rule is that the injured party must be in possession "of such information that, despite uncertainty about the outcome of a court case, he has reasonable grounds for having the question of liability assessed by the courts". However, according to Article 11 of the Norwegian Limitation Act, even if the limitation period has expired, claims for damages arising from a criminal offence may be filed during a criminal proceeding (where a debtor is found guilty) or in a separate action instituted within one year after a criminal conviction has become final.

What is also relevant for this case is Article 23(5) of Chapter II of Protocol 4 SCA, providing that ESA's decisions to impose fines on undertakings in the field of competition shall not be of a criminal law nature.

\subsubsection{Responses to preliminary questions}

The Norwegian court submitted three questions regarding an assessment of national regulations on limitation periods from a perspective of the principles of equivalence and effectiveness, which are considered legal principles in the EEA. Firstly, the court asked whether it follows from the EEA principle of equivalence that a national limitation rule that lays down a separate limitation period for damages arising from a criminal offence established by a final criminal conviction must be applied correspondingly in connection with an action for damages for infringement of Articles 53 and 54 EEA established by a final decision by ESA imposing a fine. The Norwegian Government underlined that under national law, damage claims resulting from antitrust infringements are not covered by a special limitation period connected to criminal offences because infringement decisions are treated in the same manner as other administrative decisions. The Norwegian Government claimed that "The principle of equivalence is not to be interpreted as requiring EEA States to extend their most favourable rules to all actions" (paragraph 56). ESA decisions imposing fines for antitrust breaches may be treated as criminal cases only in terms of safeguarding the rights of defendants and "such fundamental procedural guarantees are not relevant in an action for damages" (paragraph 58). Even the European Commission was not in favour of applying a principle of equivalence in this case. However, the EFTA Court claimed (paragraph 73) that "the principle of equivalence extends the general principle of equality to the law of 
remedies (see Koch and Others, cited above, paragraph 123). Specifically in the area of competition law, national rules governing actions for safeguarding rights derived from EEA law must not jeopardise the effective application of Articles 53 and 54 EEA (compare the judgment in Donau Chemie, cited above, paragraph 27 and case law cited)". The EFTA Court also said that "it follows from the principle of equivalence that national procedural law must remain neutral in relation to the origin of the rights invoked". What really counts is the severity of an infringement - in some countries, including Norway, some antitrust breaches are also subject to criminal sanctions, not only to purely administrative ones. Consequently, "if infringements subject to such ESA decisions are considered similar to infringements for which criminal sanctions would apply, the same should apply to the decisions by ESA". The EFTA Court concluded that the principle of equivalence requires that a national limitation rule that lays down a separate limitation period of one year for bringing an action for damages arising from a criminal offence that has been established by a final criminal conviction must be applied correspondingly to an action for damages for infringement of Articles 53 and 54 EEA that has been established by a final decision by ESA imposing a fine, insofar as those actions have similar purpose, cause of action and essential characteristic" (paragraph 84).

Secondly, the Norwegian court asked whether the EEA law principle of effectiveness restricts the EEA States' right to apply a limitation period of three years for bringing an action for damages for infringement of Articles 53 and 54 EEA when this limitation period is combined with a duty of investigation on the part of the injured party that could lead to the limitation period expiring before the ESA has reached a decision in a case concerning infringement of Articles 53 and 54 EEA based on a complaint from the injured party.

Thirdly, the referring court asks what elements should be taken into account in the assessment of whether the application of national limitation periods is compatible with the EEA law principle of effectiveness in competition cases of a nature and scope such as the present case. The EFTA Court decided to address both questions altogether. Responding to these questions, the EFTA Court stated that: "the principle of effectiveness does not restrict EEA States' right to apply a limitation period of three years for bringing an action for damages for infringement of Articles53 and 54 EEA when this limitation period is combined with a duty of investigation on the part of the injured party that could lead to the limitation period expiring 
before ESA has reached a decision in a case concerning infringement of Articles 53 and 54 EEA based on a complaint from the injured party, as long as the application of such a limitation period does not make it impossible or excessively difficult to bring an action for damages for infringement of EEA competition rules. That assessment must take into account the special characteristics of competition cases".

EFTA Court's judgment in case E-10/17 Nye Kystlink was a point of reference in the opinion of Advocate General Kokott in case C-637/17 Cogeco Communications Inc v. Sport TV Portugal SA and Others, delivered on 17 January $2019^{14}$. The judgment also attracted a lot of comments from practitioners $^{15}$.

\subsection{E-6/17 Fjarskipti hf. v Síminn hf.}

\subsubsection{Facts of the case}

Fjarskipti and Síminn are both companies providing general telecom services in Iceland, including mobile phone services. On 3 April 2012, the Icelandic Competition Authority found that Síminn had violated prohibitions of an abuse of a dominant position contained in Article 11 of the national Competition Act and Article 54 EEA by having applied an unlawful margin squeeze against its competitors, including Fjarskipti, in the setting of its termination rates (prices paid for terminating a call that originates in one mobile network and ends in another). Síminn lodged an appeal with the Competition Appeals Committee (Áfrýjunarnefnd samkeppnismála). By a ruling of 22 August 2012, the Competition Appeals Committee upheld the Competition Authority's decision. In March 2013, the Icelandic Competition Authority entered into a settlement with Síminn, which in fact meant that there was no final ruling of the case by the competition

\footnotetext{
${ }^{14}$ The opinion is not available in English.

${ }^{15}$ For instance, see Van Beal \& Bellis, "EFTA Court judgment on limitation period for damage claims", VBB on Competition Law 2018, 9 (2018): 12-13, https://www.vbb.com/media/Insights_ Newsletters/CNL_09_18.pdf (30 June 2019); Stibbe, “EFTA Court offers a guidance for assessing national limitation periods for follow-on damages claim”, Competition Law Newsletter, October 2018, https://www.stibbe.com/en/news/2018/october/efta-court-offers-guidance-for-assessingnational-limitation-periods-for-follow-on-damages-claims (30 June 2019). The case is also commented on in legal writings: Sven Erik Svedman, “The enforcement of EEA Agreement by the EFTA Surveillance Authority: Enhancing welfare and prosperity", in The Art of Judicial Reasoning. Festschrift in Honour of Carl Baudenbacher, eds. Gunnar Selvik, Michael-James Clifton, Theresa Haas, Luisa Lourenço, Kerstin Schwiesow, (Switzerland: Springer 2019), 74-76.
} 
authority. However, Fjarskipti kept on claiming that it had been charged highly excessive termination rates and as a result it demanded a compensation from Síminn, which rejected the claim. Fjarskipti made Article 54 EEA a base for its claim, and the court in Reykjavik decided to stay the proceeding in order to clear the content of this provision in the pending case by the EFTA Court. The judgment responding to the Icelandic court's questions was delivered on 30 May $2018^{16}$.

\subsubsection{Legal issues}

The court dispute between Fjarskipti and Síminn concentrated mainly on the interpretation of abuse of a dominant position contained in Article 54 EEA, but it also touched some procedural issues crucial for private enforcement of competition law. The latter regarded, firstly, the possibility of invoking an infringement of Article 54 EEA by a natural or legal person before a national court of EEA country. Another procedural aspect of the case was the legal status of settlements between the competition authority and an infringer. A key substantive issue analysed by the court was a potentially abusive nature (as a margin squeeze) of a termination rate applied by a dominant company on a wholesale market. The other substantive issue raised before the civil court regarded a market (wholesale or retail) where a dominant position was held in order to attribute an abusive behaviour to a company with significant market power. None of these issues were definitely resolved by the EEA Agreement or the Icelandic national competition law.

\subsubsection{Responses to preliminary questions}

The first question submitted to the EFTA Court concerned the possibility for a natural or legal person to stand up with a claim for infringement of Article 54 EEA before a domestic court as part of an effective implementation of the EEA Agreement. The answer to this question could only have been affirmative. All intervenients in the proceeding before the EFTA Court (including the Icelandic and Norwegian Governments) agreed that Article 54 EEA (as well as Article 102 TFEU) "are sufficiently precise and unconditional as not only to impose obligations on those undertakings to which they are addressed, but also to establish rights for private

\footnotetext{
${ }^{16}$ English version of the judgment at https://eftacourt.int/wp-content/uploads/2019/01/6_17__ Judgment_EN.pdf.
} 
parties", and Article 54 EEA can be "directly applicable in the sense that it may be invoked by private parties in domestic legal proceedings" (paragraph 16). Fjarskipti, the Norwegian Government, ESA and the Icelandic Competition Commission claimed that "in the absence of EEA rules, it is for the domestic legal system of each EEA State to lay down the detailed procedural rules governing actions for safeguarding rights which individuals derive directly from EEA law" (paragraph 21). Responding to the first question, the EFTA Court emphasised that there was no recognition of direct effect under the EEA Agreement. In Iceland, the EEA Agreement was specifically incorporated into domestic law and nowadays it constitutes an integral part of the internal legal order (paragraphs 25-26). The EFTA Court noticed a close similarity between Article 54 EEA and Article 102 TFEU and repeated a statement of the CoJ, namely that "the full effectiveness of Article 54 EEA would be put at risk if it were not open to an individual to claim damages for loss caused by conduct liable to restrict or distort competition" (paragraph 29). The EFTA Court also underlined that "the existence of a right to claim damages strengthens, in particular, the working of the EEA competition rules and discourages agreements or practices that are liable to restrict or distort competition" (paragraph 30).

The second preliminary question addressed to the EFTA Court concerned the significance of whether a competition authority has delivered a final ruling finding a violation of Article 54 EEA when assessing a claim for compensation for a violation of competition rules. The Antitrust Damages Directive has not been implemented in Icelandic law, and in domestic law there are no provisions corresponding to Article 9 of the Antitrust Damages Directive, pointing that a final decision of a competition authority is bounding for a civil court ruling on antitrust damage claims. However, Fjarskipti noticed that the Antitrust Damages Directive "may serve as a point of reference also in the EFTA pillar, as codification of relevant case law" (paragraph 35). The Norwegian Government and the Icelandic Competition Commission did not share this opinion, because the Antitrust Damages Directive belonged to the EU secondary law which, unlike the EU primary law, did not need to be incorporated into the EEA (paragraph 35). Still, all the participants agreed that a final ruling of a competition authority cannot be a precondition for private claims for antitrust violations, because stand-alone claims should be also commonly admissible and cannot be discouraged (paragraph 40). Answering to the second question, the EFTA Court emphasised that "it is not a prerequisite for a court's assessment of a 
damages claim for violation of competition rules that a national competition authority has handed down a final ruling finding a violation of Article 54 EEA. Where a national competition authority has given such a final ruling, EEA law does not require that the ruling is binding on the national courts in a follow-on action" (paragraph 48). In the absence of EEA law governing the procedure and remedies for violations of competition law, an issue of the significance of a final decision of a competition authority falls under the procedural autonomy of each EEA State.

The third question concerned a situation where a dominant undertaking in a wholesale market charged termination rates to its competitors such that the dominant undertaking's own retail division would be unable to make a profit if it had to bear the cost of selling telephone calls under the same circumstances. The Reykjavik court asked whether the fact that the dominant company was itself obliged to pay a termination rates to its competitors that were higher than the rate it charged them constituted an unlawful margin squeeze. All the participants of the proceeding (surely apart from Síminn) underlined that a margin squeeze, to be abusive, must produce anticompetitive effects. It is sufficient if these effects "have the potential to exclude competitors who are at least as efficient as the dominant undertaking" (paragraph 53). Síminn held that "a margin squeeze can thus not occur unless the practice excludes from the market those competitors that are as efficient as the dominant undertaking" (paragraph 54). EFTA Court's answer to the third question is the most developed part of the judgment. The Court declared that "the fact that a dominant undertaking is obliged to purchase termination services from other operators at a rate higher than its own does not preclude a finding that the dominant undertaking's own pricing practice in the form of a margin squeeze constitutes an abuse of a dominant position within the meaning of Article 54 EEA" (paragraph 70).

The fourth question focused on the scope of dominance in case of an unlawful margin squeeze: should a dominant position be held only on a wholesale market or also on a retail market to attribute such an abuse to the company? The EFTA Court claimed that a dominant position on a wholesale market is absolutely sufficient and prevailing market power on a retail market is not required (paragraph 84 ).

\subsection{E-14/11 Schenker I v. EFTA Surveillance Authority}

The cases described above (Nye Kystlink and Fjarskipti) are "pure" private enforcement cases - preliminary questions were generated out of doubts 
raised by civil courts in EEA States conducting proceedings responding to antitrust claims lodged by private entities. But the characteristics of the EFTA Court's approach towards private enforcement of competition law would not be complete without some references to the judgments in the Schenker saga ${ }^{17}$, where private claims based on antitrust law were just the background of a dispute between ESA and Schenker (judgement was delivered on 21 December $2012^{18}$ ). The latter required from ESA access to documents from antitrust proceedings in order to prepare a damage claim against Norway Post, who had been found to abuse a dominant position on a business-to-consumer parcel market in Norway ${ }^{19}$. Rules on the access to documents of the EFTA Surveillance Authority are established by Decision 407/08/COL of 27 June 2008 (hereinafter, RAD) and designed quite similarly to Regulation 1049/2001 of the European Parliament and of the Council regarding public access to European Parliament, Council and Commission documents ${ }^{20}$. Article 4(2) RAD states that the ESA "shall refuse access to a document where disclosure would undermine the protection of:

- commercial interests of a natural or legal person, including intellectual property, - court proceedings and legal advice,

- the purpose of inspections, investigations and audits, unless there is an overriding public interest in disclosure".

The EFTA Court underlined that "access to documents is the rule and that a decision refusing access is only valid if it is founded on one of the exceptions provided for by Article 4 RAD" (paragraph 125). The ESA claimed that follow-on damages claims in competition law cases only serve the purpose of defending the plaintiff's private interests and "the defence of private interests such as follow-on damages claims globally does not in itself constitute public interest grounds capable of prevailing over the presumption" (paragraph 209) - this approach eliminated the possibility to apply "public interest in disclosure" as a prerequisite that could justify access to documents in situations listed in Article 4(2) RAD as situations

\footnotetext{
${ }^{17}$ For more about the Schenker case, see Fergal O'Regan, "Fine-tuning transparency", in The EEA and the EFTA Courts: Decentred integration, ed. EFTA Court (Oxford, Portland, Oregon: Hart Publishing, 2014), 357.

${ }^{18}$ English version at https://eftacourt.int/download/14-11-judgment/?wpdmdl=1214\&masterkey=.

${ }^{19}$ ESA's Decision No. 321/10/COL 14 July 2010 (Norway Post - loyalty/discount system).

${ }^{20}$ Regulation (EC) No. 1049/2001 of the European Parliament and of the Council of 30 May 2001 regarding public access to European Parliament, Council and Commission documents, OJ 2001 L $145,43-48$.
} 
where access to documents can be refused. However, the EFTA Court did not agree with this position. It indirectly admitted that the public interest did exist in the case, since access to documents enables private enforcement of Articles 53 and 54 EEA, which "ought to be encouraged, as it can make a significant contribution to the maintenance of effective competition in the EEA" (paragraph 132) - in this sense, private enforcement of competition law may constitute an overriding public interest in the meaning of Article 4(2) RAD (paragraph 241). The EFTA Court also declared that the interest of a company that abused its dominant position on the market to avoid private actions for damages cannot be regarded as a commercial legitimate interest deserving protection. In this respect, it must be taken into account that every individual has the right to claim damages for "loss caused to him by contract or conduct which is liable to restrict or distort competition" (paragraph 189).

EFTA Court's opinion regarding the issue of third party access to documents in a context of private enforcement of competition law was appreciated by Advocate General Kokkot in his opinion on Case C681/11 Schenker $\&$ Co AG and Others, delivered on 28 February $2013^{21}$, and on Case C557/12 Kone $A G$ and Others, delivered on 30 January $2014^{22}$.

\subsection{E-5/13 Schenker V v. EFTA Surveillance Authority}

A judgment of the EFTA Court, dated from 7 July $2014^{23}$, continued the Schenker saga, resulting from the annulment of two decisions of the EFTA Surveillance Authority (the first of 25 January 2013 and the second of 18 February 2013), both regarding Schenker's public access request for an internal document belonging to the file of the antitrust proceeding conducted by ESA in the Norway Post case.

In this judgment, the EFTA Court upheld the position previously expressed in Schenker I. Referring directly to the Opinion of Advocate General Kokott in case C-557/12 Kone, the EFTA Court noticed that "specific policy considerations arise in requests for access to documents as part of follow-on damages cases brought before national courts concerning

\footnotetext{
${ }^{21}$ Opinion of Advocate General Kokott delivered on 28 February 2013, Case C681/11 Schenker \& Co AG and Others, ECLI:EU:C:2013:126.

${ }^{22}$ Opinion of Advocate General Kokott delivered on 30 January 2014, Case C557/12 Kone AG and Others, EU:C:2014:45.

${ }^{23}$ English version of the judgment at https://eftacourt.int/download/5-13-judgment-of-thecourt/?wpdmdl=1068.
} 
Articles 53 and 54 EEA. The private enforcement of these provisions ought to be encouraged, as it can make a significant contribution to the maintenance of effective competition in the EEA. While pursuing his private interest, a plaintiff in such proceedings contributes at the same time to the protection of the public interest. This thereby also benefits consumers".

The judgment in Schenker $V$ confirms that not only the case law of the EU courts, but also opinions of Advocates General can serve as a source of inspiration for the EFTA Court's jurisprudence.

\section{The EFTA Court's approach to CJEU's judgments concerning pri- vate enforcement of competition law}

What can be seen as a striking conclusion from the above analysis of the EFTA Court's case law is the fact that the importance of private enforcement of competition law in the context of the EEA Agreement is fully recognised by the EFTA Court. All the analysed judgments regarding the private enforcement of competition law strongly confirm the right of individuals "to claim damages for loss caused by conduct liable to restrict or distort competition" (E-10/17 Nye Kystlink, paragraph 71; E-6/17 Fjarskipti, paragraph 29). In the EFTA Court's view, private enforcement of competition law strengthens public enforcement of competition law: "while pursuing his private interest, a plaintiff in such proceedings contributes at the same time to the protection of the public interest" (E-10/17 Nye Kystlink, paragraph 72).

Regarding the fact that Articles 101 and 102 TFEU set a pattern for Articles 53 and $54 \mathrm{EEA}$, it is absolutely justified to check the (expected) coherence between the EFTA Court's case law and the jurisprudence of the CJEU regarding private enforcement of competition law. Surely the record of private enforcement cases in the EU and the EEA is different - the number of judgments delivered by the EFTA Court is smaller than the number of judgments adopted by the CJEU; however, this difference is not so significant as one can expect by comparing the number of member states in both organizations (three members of the EEA versus (still) twenty eight members of the $\mathrm{EU}$ ). The other striking difference is the nature of competition law violations resulting in damage claims: in the EU, almost one hundred per cent of cases (except for the Cogeco case) deal with cartels, whereas in the EEA all the judgments regarding aspects of private enforcement of competition law concern abuse of a dominant position.

It should be emphasised that, regardless of the differences pointed above, legal problems related to judicial enforcement of competition law are the 
same in the EU and in the EEA - issues analysed by the EFTA Court such as limitation periods for antitrust claims or the legal significance of a decision (or the lack of a decision) of a competition authority have been "hot potatoes" also before the EU courts. It needs to be highlighted, however, that the EFTA Court is not a blind follower of the CJEU in private enforcement cases - in Nye Kystlink, the EEA's Court stood in front of a challenge that was not experienced by the CJEU: it had to resolve complex problems concerning the application of limitation periods for damage claims. This problem has never been analysed by the CJEU in such an extent as the EFTA Court did in Nye Kystlink - the first judgment where the CJEU dealt with a national regulation on limitation periods in a broader scope (Cogeco case) was delivered almost eleven months after the Nye Kystlink judgment was adopted (good old Manfredi case raised only very basic aspects of the limitation period). To some point, EFTA's judgment in the Nye Kystlink case even preceded the CJEU's judgment on the Cogeco case.

CJEU jurisprudence, not surprisingly, constitutes a strong point of reference for the EFTA Court's arguments. A scope of references is shown in the table below.

Table 1. References to CJEU case law on private enforcement in the EFTA Court's judgments

\begin{tabular}{|c|c|}
\hline $\begin{array}{c}\text { CJEU's judgment referred to in the EFTA } \\
\text { Court's judgments }\end{array}$ & $\begin{array}{l}\text { EFTA Court's judgments referring to } \\
\text { CJEU's judgments }\end{array}$ \\
\hline C-453/99 Courage & $\begin{array}{c}\text { E-14/11 Schenker I, paragraph } 132 \\
\text { E-6/17 Fjarskipti, paragraph } 19 \\
\text { E-10/17 Nye Kystlink, paragraphs 58, 87, } 104\end{array}$ \\
\hline Joined cases C-295/04-298/04Manfredi & $\begin{array}{c}\text { E-6/17 Fjarskipti, paragraph } 19 \\
\text { E-10/17 Nye Kystlink, paragraphs } 54,58,87 \\
91,97,101,104,119\end{array}$ \\
\hline C-360/09 Pfleiderer & E-10/17 Nye Kystlink, paragraph 47, 87 \\
\hline C-199/11 Otis \& Others & E-10/17 Nye Kystlink, paragraphs 47, 104 \\
\hline C-536/11 Donau Chemie & $\begin{array}{c}\text { E-10/17 Nye Kystlink, paragraphs } 44,47 \\
73,87,104\end{array}$ \\
\hline C-557/12 Kone \& Others & $\begin{array}{c}\text { E-5/13 Schenker } V \text {, paragraphs } 134 \\
\text { E-10/17 Nye Kystlink, paragraphs } 47,87,104\end{array}$ \\
\hline $\begin{array}{c}\text { C-352/13 CDC Hydrogen Peroxide Cartel } \\
\text { Damage Claims v. Commission }\end{array}$ & E-14/11 Schenker I, paragraphs 189 \\
\hline
\end{tabular}

Source: own analysis 
As Table 1 shows, the EFTA Court is fully aware of CJEU's jurisprudence on various aspects of private enforcement of competition law and is eager to justify its own argumentation with quotations from the EU cases. The biggest number of references is made to the milestone case of Manfredi, but more recent judgments are also mentioned by the EFTA Court. The judgment in case E-10/17 Nye Kystlink seems to represent this judicial tendency in the highest degree, because the number of references to the EU cases in this judgment is the most impressive.

\section{Final remarks}

Frequent references to CJEU jurisprudence in order to support its own views can be considered as a sign of a will to guarantee the cohesion of case law on private enforcement in the EU and in the EEA. Regarding the fact that the EEA Agreement originated (at least in terms of basic economic ideas and concepts) from the (current) Treaty on the Functioning of the EU, the common analytical framework and coherent conclusions in private enforcement cases could be taken for granted. The analysis of private enforcement cases in the EFTA Court's jurisprudence and, specifically, the analysis of references to the CJEU's case law made by the EFTA Court confirmed a full (to the most possible extent) coherence of enforcement of EU and EEA competition rules.

It must be noted that most of the legal problems the EFTA Court has dealt with in its judgments have been at least partly solved in the EU by the Antitrust Damages Directive. This conclusion should be treated as an important reason for the incorporation of Directive 2014/104/EU in the EEA, which has not occurred so far. Nowadays, EFTA Court's statements on damage claims resulting from violations of competition law must be certainly based on vast references to principles of effectiveness and equivalence. Incorporating the Antitrust Damages Directive into the EEA legal system would make it unnecessary to use these general principles as anchors for the EFTA Court's reasoning. It is quite probable that future judgments of EFTA Court in competition cases will glitter with links to the Antitrust Damages Directive - this could have a positive impact on a process of an incorporation of the Directive ${ }^{24}$.

\footnotetext{
${ }^{24}$ For instance, Romina Polley expresses the opinion that Directive 2014/104/EU should be incorporated into EEA law also in order to provide a legal certainty in the area of third party access to documents in cartel proceedings across the EEA - Romina Polley, "Third party to file in competi-
} 
The analysis of EFTA Court's jurisprudence on private enforcement of competition law can be regarded as the basis for some conclusions on the institutional position of the EFTA Court and its role in guaranteeing a coherence of EEA and EU law. Fulfilling this role is extremely important from the perspective of Article 3 EEA, which requires the contracting parties to take all appropriate measures, whether general or particular, to ensure the fulfilment of the obligations arising from the Agreement; this normative context even allows some authors to conclude that both the EFTA Court and the CJEU are, in fact, EEA courts ${ }^{25}$. The approach of the EFTA Court to damage claims resulting from infringements of Articles 53 and 54 EEA seems to be absolutely mature - by highlighting the importance of private enforcement of competition law, the EFTA Court takes full responsibility for the effectiveness of competition rules. In that manner, EFTA Court's jurisprudence regarding damage claims confirms the opinions that this Court "seems perfectly aware of (...) its role as a useful and unique complement to the EU Courts" and "its impact on the business is undoubtedly more important than it could have been anticipated when it was created" 26 .

Finally, EFTA Court's judgments regarding private enforcement of competition law can be seen as an inspiration for EU and national courts. Mutual inspiration between the EFTA Court and the CJEU can also be reflected in opinions of Advocates General delivered in competition cases.

\section{Bibliography}

Fredriksen, Halvard H. “The two EEA Courts - a Norwegian perspective”. https://pdfs. semanticscholar.org/a71b/43a925370c87d40ecb9f4635907a2a007767.pdf.

Morgan de Rivery, Eric and Alexander Fall. "The EFTA Court - the Court of Business law?". In The EEA and the EFTA Courts: Decentred integration, edited by EFTA Court, 387-406. Oxford: Hart Publishing, 2014.

O'Regan, Fergal. "Fine-tuning transparency". In The EEA and the EFTA Courts: Decentred integration edited by EFTA Court, 337-367. Oxford: Hart Publishing, 2014.

tion cases", in The EEA and the EFTA Courts: Decentred integration, ed. EFTA Court (Oxford, Portland, Oregon: Hart Publishing, 2014), 436.

${ }^{25}$ For instance, see Halvard H. Fredriksen, "The two EEA Courts - a Norwegian perspective", https://pdfs.semanticscholar.org/a71b/43a925370c87d40ecb9f4635907a2a007767.pdf.

${ }^{26}$ Eric Morgan de Rivery and Alexandre Fall, “The EFTA Court - the Court of Business law?”, in The EEA and the EFTA Courts Courts: Decentred integration, ed. EFTA Court (Oxford, Portland, Oregon: Hart Publishing, 2014), 405. 
Polley, Romina. "Third party to file in competition cases". In The EEA and the EFTA Courts: Decentred integration, edited by EFTA Court, 435-458. Oxford: Hart Publishing, 2014.

Stibbe, "EFTA Court offers a guidance for assessing national limitation periods for follow-on damages claim”. Competition Law Newsletter, October 2018. https://www. stibbe.com/en/news/2018/october/efta-court-offers-guidance-for-assessing-nationallimitation-periods-for-follow-on-damages-claims.

Svedman, Sven Erik. "The enforcement of EEA Agreement by the EFTA Surveillance Authority: Enhancing welfare and prosperity". In The Art of Judicial Reasoning. Festschrift in Honour of Carl Baudenbacher, edited by Gunnar Selvik, Michael-James Clifton, Theresa Haas, Luísa Lourenço, and Kerstin Schwiesow, 65-78. Switzerland: Springer, 2019.

Van Beal \& Bellis. "EFTA Court judgment on limitation period for damage claims". VBB on Competition Law 9, 2018, 12-13. https://www.vbb.com/media/Insights_ Newsletters/CNL_09_18.pdf. 